УДК 342.56:375

DOI https://doi.org/10.32849/2663-5313/2020.3.21

Ганна Васіна,

здобувач Науково-дослідного інституту публічного прав

\title{
ПРАВОВА ПРИРОДА ПУБЛІЧНОЇ АДМІНІСТРАЦІї ІСПАНІЇ ТА УКРАЇНИ: КОМПАРАТИВІСТИЧНА ХАРАКТЕРИСТИКА
}

У статті здійснена компаративістична характеристика юридичної природи публічної адміністрації Іспанії та України. Розкрита методологія формування меж правового регулювання адміністративного права Іспанії та України. Визначено, що предмет адміністративного права іспанські вчені визначають негативно, відмежовуючи важливі суспільні відносини від законодавчої, судовоі діяльності та кримінальної відповідальності, украйнські вчені також здійснюють негативне відмежування предмета адміністративного права. Додатково при иьому вони віднімають від сфери нормативного впливу адміністративного права політичну діяльність та діяльність, спрямовану на задоволення приватних інтересів, та доводять, що публічне адміністрування здійснюється виключно з метою задоволення публічного інтересу. Наголошено, що правовий режим функиіонування публічної адміністрації в Іспанії нерозривно пов'язаний із реалізачією основного завдання - ефективного наданням людям і соиіальним групам адміністративних послуг, стандарти яких чітко прописані в спеціальному законі про державні адміністрації та загальний адміністративний порядок, шляхом регламентації адміністративних прочедур - загальних, змішаних та автономій. Доведено, що для України нагальною є розробка комплексного закону про публічну адміністрацію та адміністративні процедури ї̈ діяльності, який доцільно назвати «Адміністративно-процедурний кодекс України» і в якому об'єднати усі положення, що стосуються правового статусу публічної адміністрачії, їх посадових осіб, та засадничі положення щодо надання усіх без винятку адміністративних послуг. Зроблено висновок, що теорія і практика діяльності публічної адміністрачії в Іспанії є грунтовно розробленою, в Україні ї̈ розроблення перебуває на початковій стадії. Конституиійні норми Іспанії щодо публічної адміністрачії є логічними, конкретними та досконалими, в Україні - гуманістичні, однак не конкретні і такі, що можуть трактуватися по-різному. Структура публічної адміністраиії Іспанії та ї̈ правове регулювання є досконалим, в Україні є необхідність розробки Адміністративно-прочедурного кодексу.

Ключові слова: адміністративна діяльність, адміністративне право, Іспанія, компаративістичні характеристика, публічна адміністрація, структура публічної адміністрації, Україна, юридична природа.

Постановка проблеми. Більшість країнучасниць СС досягли значних успіхів у забезпеченні належних умов для розвитку економіки та соціального забезпечення громадян. Здобути такі результати не можливо без публічної адміністрації. Адже саме на неї у повному обсязі покладається адміністративна функція виконавчої влади та надання якісних адміністративних послуг фізичним і юридичним особам.

Серед держав-членів ЄС для нас цікавим $є$ досвід Іспанії. Адже, незважаючи на віддаленість від України, вона пройшла дещо схожий шлях від диктатури до демократії в XX столітті. Зараз це розвинена індустріально-аграрна країна, яка за обсягом промислової продукції в кінці ХХ ст. посідала 5-е місце в Свропі і 8-е у світі, із середньою зарплатою приблизно 21 тис євро на рік на одного підданого. Досягти такого стану можуть тільки ефективні, контрольовані суспільством і судом посадові особи публічної адміністрації.

Україна за останні роки також досягла значних успіхів у тому числі у реформуванні різноманітних суб'єктів публічної адміністрації. Проте це ще не привело до якісної зміни стану публічного адміністрування, який би задовільнив український народ.

Іншими словами, $є$ нагальна необхідність виявляти, критично аналізувати і запозичувати іспанський дослід публічного адміністрування.

Огляд останніх досліджень. До теорії i практики компаративістики зверталися деякі вчені-адміністративісти. Серед них слід виділити В. Авер'янова, С. Бандуру, О. Бандурку, В. Галунька, Е. Гарсія Де Ентреpiї, О. Кресіна, О. Кузьменко, Ю. Лемішко, Є. Павліченко, О. Погрібного, А. Саїдова, 
О. Тихомирова, К. Шонбергера та ін. Проте безпосередньо проблематикою компаративістичного аналізу адміністративного права Іспанії і України вони не займалися, а зосереджували свою увагу на більш загальних спеціальних чи суміжних викликах.

Мета статті полягає в тому, щоб на основі теорії адміністративного права Іспанії та України, національних законодавства, поглядів на цю проблематику вчених у галузі адміністративного права виявити, проаналізувати та узагальнити юридичну природу публічної адміністрації Іспанії та України.

Виклад основного матеріалу. Від великої французької революції (1779-1804рр.) в Іспанії зародилося адміністративне право. Протягом першої половини минулого століття публічна адміністрація ототожнюється з виконавчою владою в рамках конституційних рамок принципу поділу влади. Тоді адміністративне право було особливим правовим режимом виконавчої влади. У середині XIX століття вперше в Німеччині державу було визнано юридичною особою. Таким чином, ïï відносини з приватними фізичними і юридичними особами почали будуватися за законом. Як наслідок, публічне адміністрування спочатку ототожнювалось з одним 3 органічних та індивідуалізованих повноважень держави - здійсненням виконавчої влади, згодом вона була доповнена питаннями врегулюванням взаємовідносин держави і людини [1].

При цьому треба підкреслити, що перший закон, який регулював правовий режим державних адміністрацій, в Іспанії був прийнятий ще 1889 р., а наступні - в 1957 р. (про правовий режим державної адміністрації) та 1958 р. (про адміністративну процедуру) [3]. В умовах сьогодення юридична природа публічної адміністрації в Іспанії насамперед регулюється Конституцією Іспанії (1978 р.) [2] та спеціальним Законом Іспанії «Про правовий режим державних адміністрацій та загальний адміністративний порядок» (1992 р.)

В Україні адміністративне право зародилося в період входження українських земель до складу Російської та Австро-Угорської імперій, набагато пізніше від Іспанії, на початку XX століття. У короткий період незалежності в умовах національно-визвольних змагань (1917-1920рр.) воно динамічно розвивалось. Однак після окупації українських земель російськими більшовиками на довгий час припинило своє існування.

Відновлення адміністративного права почало здійснюватися після проголошення Україною незалежності (1992р.). Однак спочатку воно розвивалось на засадах рецепції радянського адміністративного права. І тільки після прийняття Конституції України (1996р.) [4], Концепції адміністративної реформи в Україні [5], визнання більшістю вчених-адміністративістів людиноцентристської теорії адміністративного права [6] розпочалось справжне будівництво адміністративного права України на засадах євроатлантичних цінностей. Перший закон про державну службу був прийнятий в Україні в $1993 \mathrm{p}$.

Отже, в Україні із відставанням більше ніж на століття від Іспанії почало розвиватися адміністративне право, формуватися засади юридичної природи змісту і сутності публічної адміністрації. Що стосується новітнього адміністративного права, яке будується на засадах цінностей європейської спільноти, то воно почало формуватися як в Україні, так і в Іспанії після прийняття демократичних конституцій: в Іспанії в 1978 р., а в Україні - в 1996 р.

Юридична природа публічної адміністрації $є$ похідною від тієї сфери суспільних відносини, яку вона має регулювати на основі норм адміністративного права. В українській юридичній науці сфера правового регулювання галузі права отримала назву «предмет галузі». Ми вважаємо за доцільне використати його в нашому дослідженні як ємну наукову категорію.

Іспанські вчені доводять, що спроба виділити абстрактну державну функцію управління, побудувати на ній формальний предмет адміністративного права як дисципліни була одним із найдовших і найтонших зусиль в історії іспанської науки, а також одним із найбільш марних. Втома від цих тривалих діалектичних зусиль відбилася в дивовижній остаточній формулі негативного визначення: публічним адмініструванням стала вважатися будь-яка діяльність держави, окрім законодавчої, судової діяльності та кримінальної відповідальності [1].

Схожий, але більш комплексний підхід до предмета адміністративного права сповідують деякі українські вчені. Так, профеcop В. Галунько доводить, що публічне адміністрування як форма реалізації публічної влади характеризується: 1) зовнішнім виразом реалізації завдань (функцій) виконавчої влади; 2) адміністративною діяльністю публічної адміністрації; 3) здійснюється 3 метою задоволення публічного інтересу; 4) негативно відмежовується від: законодавчої діяльності; здійснення правосуддя; політичної діяльності виконавчої влади; діяльності, спрямованої на задоволення приватних інтересів [8]. 
Отже, предмет адміністративного права іспанські вчені визначають негативно, відмежовуючи важливі суспільні відносини від законодавчої, судової діяльності та кримінальної відповідальності. У свою чергу українські вчені також здійснюють негативне відмежування предмета адміністративного права. При цьому додатково ще віднімають від сфери нормативного впливу адміністративного права політичну діяльність та діяльність, спрямовану на задоволення приватних інтересів. Крім того, вони доводять, що публічне адміністрування характеризується зовнішнім виразом реалізації функцій виконавчої влади, адміністративною діяльністю публічної адміністрації та здійснюється виключно з метою задоволення публічного інтересу.

В іспанській теорії адміністративного права велика увага приділяється публічній адміністрації як юридичній особі. Перше, на що звертають увагу вчені-адміністративісти, це те, що публічне адміністрування не є для адміністративного права стабільною функцією. Мобільність адміністративної діяльності є головною перешкодою на шляху до спроби чітко окреслити матеріальні чи формальні межі публічного адміністрування. Функції та адміністративна діяльність, яку повинна здійснювати публічна адміністрація, залежать від історичного етапу розвитку держави. Вони є змінними та суттєво залежать від соціального попиту, який є різним для кожної культурної епохи. Також вони залежать від соціально-економічного розвитку держави. Іспанські вчені наголошують, що доктрина публічного адміністрування в умовах сьогодення не може бути догматичною. Адже феномен публічних компаній привів до того, що в адміністративному праві почали застосовувати норми приватного права, і навпаки, в діяльності приватних компаній знайшли своє використання норми публічного права. Це стосується насамперед таких важливих для суспільства галузей, як залізничний транспорт, транспортування і розподіл електроенергії і газу та ін. [1].

Структурний взаємозв'язок між реальністю існування публічної адміністрації та правовою системою здійснюється не шляхом розгляду її як сукупності органів, а через розуміння іх як юридичних осіб. В адміністративному праві публічна адміністрація $\epsilon$ юридичною особою. Ця персоналізація $\epsilon$ тим фактором, який залишається доти, доки він не змінюється внаслідок ліквідації (реорганізації) органу чи зміни (уточнення) їх адміністративно-правових функцій. Доти, доки публічна адміністрація існує як юридична особа, вона є суб'єктом адміністра- тивного права, який видає владні розпорядження, укладає договори, є власником майна та несе юридичну відповідальність Таким чином, уособлення публічної адміністрації $€$ основною і неодмінною умовою існування адміністративного права. Слід сказати, що такий підхід не зовсім відповідає класичній теорії німецької школи публічного права, яка стверджувала, що правосуб'єктність має держава в цілому, а не її публічні органи. Іспанські вчені доводять, що як юридична особа держава виступає насамперед як суб'єкт міжнародного права [1].

В Україні публічній адміністрації як юридичній особі вчені-адміністративісти не приділяють великої уваги. Наприклад, професор Р. Мельник доводить, що в Україні категорія «публічна адміністрація» не має законодавчого визначення. Тільки в Кодексі адміністративного судочинства України розкрита категорія «суб'єкт владних повноважень». Проте слід розуміти, що поняття «суб'єкт владних повноважень» не відповідає усій об'єктивній сукупності наявних суб'єктів публічної адміністрації, оскільки в розумінні КАСУ суб'єктами владних повноважень визнаються ті, хто здійснюють так звані владні управлінські функції. На його думку, із посиланням на європейських вчених, публічна адміністрація розуміється як: 1) сукупність органів, установ та організацій, які здійснюють адміністративні функції; 2) адміністративна діяльність, що здійснюється цією адміністрацією в інтересах суспільства; 3) сфера управління публічним сектором тією самою публічною адміністрацією. Також ним наводиться трактування цієї категорії у Рекомендації № R (84) 15 Комітету міністрів Ради Європи державам-членам стосовно публічно-правової відповідальності за спричинену шкоду, прийнятій 11 вересня 1984 р. на 375-й нараді заступників міністрів, а саме, публічна влада розуміється як: а) будь-який публічно-правовий суб'єкт будь-якого виду чи рівня (в тому числі держава, регіон, провінція, муніципалітет, незалежний публічно-правовий суб'єкт); та b) будь-яка приватна особа при здійсненні нею прерогатив офіційної влади [9].

Отже, теорія і практика діяльності публічної адміністрації в Іспанії $є$ грунтовно розробленою: зокрема, є законодавче її визначення. В Україні як теорія так і практика діяльності публічної адміністрації перебуває на початковій стадії. Законодавче визначення відсутне. Відповідно, вченим-адміністративістам доводиться створювати доктринальні підходи до цієї проблеми, використовуючи вторинні акти ЄС. А якщо додати до цієї 
проблеми відсутність Адміністративно-процедурного кодексу, то глибинна проблеми збільшується. На наш погляд, $є$ нагальна потреба прийняти закон України «Про публічну адміністрацію та адміністративні процедури її діяльності».

Як в Іспанії, так в Україні існування та діяльність публічної адміністрації мають конституційне коріння. Згідно зі ст. 103 Конституції Іспанії публічна адміністрація має обєктивно служити загальним інтересам та діяти відповідно до принципів ефективності, ієрархії, децентралізації та координації з повним підпорядкуванням закону і праву. Органи публічної адміністрації створюються, управляються та координуються відповідно до спеціального закону, який регулює правовий статус публічних службовців, правила доступу до публічної служби дієздатних осіб відповідно до засад репутації, неупередженості, особливостей проходження публічної служби та дотримання гарантій неупередженості. Ст. 106 Основного Закону Іспанії визначила, що контроль за діяльністю публічної адміністрації здійснюють суди. Вони контролюють регуляторну владу та законність її адміністративних дій Фізичні особи на умовах, встановлених законом, мають право на відшкодування державою будь-якої шкоди, яка є наслідком діяльності публічних служб [2]. При цьому треба розуміти, що закон в Іспанії не є волею держави - це загальна воля, конкретний вираз, за яким живе народ. Публічна адміністрація має правосуб'єктність. Розуміння публічної адміністрації позбавлено будь-якої містики. Публічна адміністрація - це інструментальна організація, яка завжди виконує закони як суб’єкт, що видає акти, декларації, укладає договори та відповідає за нанесені збитки за рішенням суду [1].

Конституція України визначила, що носієм суверенітету і єдиним джерелом влади в Україні є народ. Народ здійснює владу безпосередньо і через органи державної влади та органи місцевого самоврядування (стаття 5). Державна влада в Україні здійснюється на засадах її поділу на законодавчу, виконавчу та судову. Органи законодавчої, виконавчої та судової влади здійснюють свої повноваження у межах, встановлених Конституцією, і відповідно до законів України (стаття 6) [4].

Отже, з погляду норм конституційного права в Іспанії чітко і логічно прописані засади існування і функціонування публічної адміністрації, а саме визначено, що публічна адміністрація має об'єктивно служити загальним інтересам. Також прописано, що органи публічної адміністрації створюються, управляються та координуються відповідно до спеціального закону, а контроль за їхньою діяльністю здійснюють суди. В Україні задекларовано, що носієм суверенітету і єдиним джерелом влади в Україні є народ, який здійснює владу безпосередньо і через органи державної влади та органи місцевого самоврядування. Державна влада здійснюється на засадах їі поділу на законодавчу, виконавчу та судову, їі органи здійснюють свої повноваження у межах, встановлених Конституцією, і відповідно до законів України.

Отже, конституційні норми Іспанії щодо публічної адміністрації є логічними, конкретними та, на наш погляд, досконалими. В Україні - гуманістичні, однак не конкретні і такі, що можуть по-різному трактуватися, що в умовах політичної заангажованості деяких суддів Конституційного суду України призводить до несприятливих для громадян наслідків.

Теорія права доводить, що зв'язок між законом та суддею є прямим, без будь-якого посередника, який може втручатися в його діяльність під час прийняття рішення. На відміну від цього публічна адміністрація є повністю організованою та структурованою, а їі діяльність ієрархічно підпорядкована. Посадові особи публічної адміністрації - це прості агенти своєї організації. Публічна адміністрація не має представницьких функцій громади. Вона є організацією, яка надає послуги громаді [1]. Це теоретичне твердження є таким, що рівною мірою характеризує юридичну природу публічної адміністрації як Іспанії, так і України.

На думку іспанських вчених, не існує однієї публічної адміністрації. Одночасно здійснює свою діяльність сукупність публічних адміністрацій, які вступають в адміністративно-правові відносини. Разом із державною адміністрацією працюють автономні громади, місцеві адміністрації: провінції, муніципалітети, місцеві меншини. Кожен 3 них має свою персональну правосуб'єктність та безліч інституційних чи корпоративних організацій. Ця сукупність суб'єктів публічних адміністрацій, наділених правосуб'єктністю, існує та діє у сфері адміністративного права. Наприклад, кількість муніципалітетів в Іспанії досягає восьми тисяч [1].

Правовий режим публічних адміністрацій встановлюється на основі конституційної концепції. Він виходить за рамки правил внутрішнього функціонування публічної адміністрації та інтегрує правила взаємодії її iз суспільством. А найголовніше, розкриває конкретні інструменти, які мають ефективно забезпечувати конституційні права людини та соціальних груп. 
Конституція Іспанії позділяе правові режими адміністративної діяльності публічних адміністрацій залежно від (видів) рівнів процедур, які вони надають: загальні адміністративні процедури; спільні адміністративні процедури; та адміністративні процедури, які надаються автономними громадами. Закон про правовий режим державних адміністрацій та загальний адміністративний порядок (1992 р.) встановлює мінімальні гарантії для підданих та іноземців, які перебувають на території Іспанії на законних підставах, щодо отримання адміністративної процедури діяльності. При цьому правове регулювання адміністративних процедур автономних громад завжди повинно поважати правила загальних процедур, що входять до компетенції держави (загальної адміністративної процедури).

Іншими словами, правовий режим функціонування публічної адміністрації в Іспанії нерозривно пов'язаний із реалізацією основного завдання - ефективного наданням людям і соціальним групам адміністративних послуг, стандарти яких чітко прописані в спеціальному законі про державні адміністрації та загальний адміністративний порядок, шляхом регламентації адміністративних процедур - загальних, змішаних та автономій [1].

3 урахуванням положень Закону Іспанії про судово-адміністративну юрисдикцію від 13 липня 1998 р., на основі аналізу актів, які оскаржуються в системі судів адміністративної юстиції, зазначимо, що до системи публічної адміністрацію слід віднести: 1) державну адміністрацію; 2) адміністрації автономних громад; 3) субєктів, що входять до складу місцевої адміністрації; 4) суспільно-правові утворення, які залежать від держави або пов'язані з нею, автономними громадами або місцевими утвореннями [11].

Отже, структура публічної адміністрації Іспанії складається із системи державної адміністрації, адміністрації автономних громад та місцевих адміністрацій - провінції, муніципалітету, місцевої меншини.

В Україні до основних суб'єктів публічної адміністрації вчені-адміністративіти відносять: 1) органи виконавчої влади; 2) суб'єктів місцевого самоврядування; 3) суб'єктів делегованих повноважень: 3.1) громадські об'єднання; 3.2) інших суб'єктів під час здійснення делегованих законодавством виконавчих функцій [10].

Провідними суб'єктами публічної адміністрації в Україні є органи виконавчої влади, які складаються із вищого органу виконавчої влади - Кабінету Міністрів України (Уряду України), центральних та місцевих органів виконавчої влади. Згідно з Конституцією та спеціальним законом Кабінет Міністрів України відповідальний перед Президентом України і Верховною Радою України, підконтрольний і підзвітний Верховній Раді України. Він забезпечує державний суверенітет і економічну самостійність України, здійснення внутрішньої і зовнішньої політики держави, реалізацію стратегічного курсу держави на набуття повноправного членства України в Свропейському Союзі та в Організації Північноатлантичного договору, забезпечує проведення фінансової, цінової, інвестиційної та податкової політики; політики у сферах праці й зайнятості населення, соціального захисту, освіти, науки і культури, охорони природи, екологічної безпеки і природокористування та ін. [2; 12$]$.

Систему центральних органів виконавчої влади становлять міністерства України та інші центральні органи виконавчої влади. Система центральних органів виконавчої влади є складовою частиною системи органів виконавчої влади, вищим органом якої є Кабінет Міністрів України. Міністерства забезпечують формування та реалізують державну політику в одній чи декількох сферах інші центральні органи виконавчої влади виконують окремі функції з реалізації державної політики. Повноваження міністерств, інших центральних органів виконавчої влади поширюються на всю територію держави та ін. [2; 13].

Місцеві державні адміністрації на відповідній території забезпечують: виконання Конституції та законів України, актів Президента України, Кабінету Міністрів України, інших органів виконавчої влади; законність і правопорядок; додержання прав і свобод громадян; виконання державних i регіональних програм соціально-економічного та культурного розвитку, програм охорони довкілля, а в місцях компактного проживання корінних народів і національних меншин також програм їх національно-культурного розвитку. Враховуючи ту обставину, що у складі України є Автономна республіка Крим, то Урядом АРК є Рада міністрів Автономної Республіки Крим. Голова Ради міністрів АРК призначається на посаду та звільняється з посади Верховною Радою Автономної Республіки Крим за погодженням із Президентом України [2; 14].

Місцеве самоврядування є правом територіальної громади - жителів села чи добровільного об'єднання у сільську громаду жителів кількох сіл, селища та міста - самостійно вирішувати питання місцевого значення в межах Конституції і законів України. Місцеве самоврядування в Україні - це гарантоване державою право та реальна 
здатність територіальної громади - жителів села чи добровільного об'єднання у сільську громаду жителів кількох сіл, селища, міста самостійно або під відповідальність органів та посадових осіб місцевого самоврядування вирішувати питання місцевого значення в межах Конституції і законів України. Місцеве самоврядування здійснюється територіальними громадами сіл, селищ, міст як безпосередньо, так і через сільські, селищні, міські ради та їх виконавчі органи, а також через районні та обласні ради $[2 ; 15]$.

При цьому треба зазначити, що посадові особи органів виконавчої влади обіймають посади державної служби, які визначені структурою і штатним розписом первинної структурної одиниці державного органу з установленими відповідно до законодавства посадовими обов’язками у межах повноважень, визначених спеціальним законом [16]. Аналогічно посадові особи органів місцевого самоврядування як особи, що працюють в органах місцевого самоврядування, мають відповідні посадові повноваження щодо здійснення організаційно-розпорядчих та консультативно-дорадчих функцій і отримують заробітну плату за рахунок місцевого бюджету [17].

Отже в Україні існує складна, багаторівнева система джерел адміністративного права суб'єктів публічної адміністрації, які пов'язані між собою за вертикаллю, так i за горизонталлю. Вона є значно складнішою, ніж в Іспанії, хоча остання має більш складну адміністративно-правову будову. Як вже доводилось вище, в Україні нагальною $є$ розробка комплексного закону про публічну адміністрацію та адміністративні процедури ï діяльності, який, враховуючи законотворчу традицію, доцільно назвати «Адміністративно-процедурний кодекс України» й об'єднати в ньому усі положення, що стосуються правового статусу публічної адміністрації, її посадових осіб, та засадничі положення щодо надання усіх без винятку адміністративних послуг, залишивши законодавчу можливість конкретизувати адміністративні процедури в спеціальних галузевих законах.

\section{Висновки}

Усе вищенаведене дає можливість сформулювати такі компаративістичні особливості юридичної природи публічної адміністрації Іспанії та України:

1) предмет адміністративного права іспанські вчені визначають негативно, відмежовуючи важливі суспільні відносини від законодавчої, судової діяльності та кримінальної відповідальності, українські вчені також здійснюють негативне відмежування предмета адміністративного права. Додатково при цьому вони віднімають від сфери нормативного впливу адміністративного права політичну діяльність та діяльність, спрямовану на задоволення приватних інтересів, та доводять, що публічне адміністрування здійснюється виключно з метою задоволення публічного інтересу;

2) теорія і практика діяльності публічної адміністрації в Іспанії є грунтовно розробленою, зокрема, є законодавче іiї визначення, яке відсутнє в Україні. Загалом зроблено висновок, що теорія і практика діяльності публічної адміністрації в Україні перебуває на початковій стадії;

3) конституційні норми Іспанії щодо публічної адміністрації є логічними, конкретними та досконалими, в Україні - гуманістичні, однак не конкретні і такі, що можуть трактуватися по-різному;

4) структура публічної адміністрації Іспанії складається із системи державної адміністрації, адміністрації автономних громад та місцевих адміністрацій - провінції, муніципалітету, місцевої меншини;

5)в Україні існує складна, багаторівнева система джерел адміністративного права, що регулюють правовий статус та адміністративну діяльність публічної адміністрації, вони є значно складнішими, ніж в Іспанії;

6) для Україні нагальною $є$ розробка комплексного закону про публічну адміністрацію та адміністративні процедури іï діяльності, який доцільно назвати «Адміністративно-процедурний кодекс України» й об'єднати в ньому усі положення, що стосуються правового статусу публічної адміністрації, її посадових осіб, та засадничі положення щодо надання усіх без винятку адміністративних послуг.

\section{Список використаних джерел:}

1. Eduardo García De Enterría. Curso De Derecho Administrativo. Decimoquinta Edición. Editor: Thomson Reuters (Legal) Limited / Civitas, 2011. El Libro Tiene 872 Página.

2. La transición política. La Constitución de 1978 y el Estado de las Autonomías. 2005. URL: http://www.historiasiglo20.org/HE/16a-1.htm (дата звернення: 02.02.2020).

3. Ley $30 / 1992$, de 26 de noviembre, de Régimen Jurídico de las Administraciones Públicas y del Procedimiento Administrativo Común. 1999. URL: https://www.boe.es/buscar/doc. php?id=BOE-A-1992-26318 (дата звернення: 02.02.2020)

4. Конституція України. Відомості Верховної Ради України. 1996. № 30. Ст. 141. 
5. Концепція адміністративної реформи в Україні : затверджена Указом Президента України від 22 липня 1998 р. № 810 / Верховна Рада України. URL: https://zakon.rada.gov.ua/laws/ show/333-2014-p (дата звернення: 12.02.2020).

6. Аверянов В. Людиноцентристська ідеологія як основа реформування українського адміністративного права в умовах інтеграційного процесу. Держава та регіони. Серія «Право». 2010 . Вип. 2. С. 87-92.

7. Про службу в органах місцевого самоврядування : Закон України від 7 червня 2001 р. № 2493-III / Верховна Рада України. URL: https:// zakon.rada.gov.ua/laws/show/2493-14 (дата звернення: 12.01.2020).

8. Адміністративне право України. Т. 1. Загальне адміністративне право: навчальний посібник / В.В.Галунько, В.І. Курило, С.О. Короєд, О. Ю. Дрозд, І. В. Гиренко, О. М. Єщук, І. М. Риженко, А. А. Іванищук, Р. Д. Саунін, І. М. Ямкова ; за ред. проф. В. В. Галунька. Херсон : Грінь Д. С., 2015. 272 с.

9. Мельник Р. С., Бевзенко В. М. Загальне адміністративне право : навчальний посібник / за заг. ред. Р. С. Мельника. Київ : Ваіте, 2014. 376 с.

10. Адміністративне право України. Т. 1. Загальне адміністративне право: навчальний посібник / В.В.Галунько, В. І. Курило, С. О. Короєд, О. Ю. Дрозд, І. В. Гиренко, О. М. Єщук, І. М. Риженко, А. А. Іванищук, Р. Д. Саунін, І.М.Я Ямкова : за ред. проф. В. В. Галунька. Херсон : Грінь Д. С., 2015. 272 c
11. Ley 29/1998, de 13 de julio, reguladora de la Jurisdicción Contencioso-administrativa. 1998. URL: https://www.boe.es/buscar/pdf/1998/BOEA-1998-16718-consolidado.pdf (дата звернення: 12.12.2019).

12. Про Кабінет Міністрів України : Закон України від 27 лютого 2014 р. № 794-VII / Верховна рада України. 2014. URL: https://zakon. rada.gov.ua/laws/show/794-18 (дата звернення: 12.12.2019).

13. Про центральні органи виконавчої влади : Закон України від 17 березня 2011 р. № 3166-VI / Верховна рада України. 2014. URL: https://zakon. rada.gov.ua/laws/show/3166-17 (дата звернення: 12.12.2019).

14. Про місцеві державні адміністрації : Закон України від 9 квітня 1999 р. № 586-XIV. URL № 586-XIVhttps://zakon.rada.gov.ua/laws/show/ 586-14 (дата звернення: 12.12.2019).

15. Про місцеве самоврядування в Україні : Закон України від 21 травня 1997 р. № 280. URL: https://zakon.rada.gov.ua/laws/show/280/97-вр (дата звернення: 12.12.2019).

16. Про державну службу : Закон України від 10 грудня 2015 р. № 889-VIII. URL: https:// zakon.rada.gov.ua/laws/show/889-19 (дата звернення: 12.12.2019).

17. Про службу в органах місцевого самоврядування : Закон України від 7 червня 2001 р. № 2493-III. URL: https://zakon.rada.gov.ua/laws/ show/2493-14 (дата звернення: 12.12.2019).

The article deals with the comparative characteristics of the legal nature of the public administration of Spain and Ukraine. The methodology of forming the boundaries of legal regulation of administrative law of Spain and Ukraine is disclosed. It is determined that the subject matter of administrative law is determined by Spanish scholars by negatively distinguishing important social relations from legislative, judicial activity and criminal responsibility, Ukrainian scientists also make a negative distinction between the subject of administrative law. In addition, they subtract political activity and activities aimed at satisfying private interests from the sphere of regulatory influence of administrative law and positively prove that public administration is carried out solely for the purpose of satisfying the public interest. It is emphasized that the legal regime of functioning of public administration in Spain is inextricably linked with the implementation of the basic task - effective provision of administrative services to people and social groups, the standards of which are clearly stated in the special law on state administrations and general administrative procedure, through the regulation of administrative procedures - general, mixed, and autonomy. It is proved that it is essential for Ukraine to develop a comprehensive law on public administration and administrative procedures of its activities, which should be called "Administrative Procedure Code of Ukraine" in which to integrate all provisions concerning the legal status of public administration, their officials and basic provisions for providing all administrative services without exception. It is concluded that the theory and practice of public administration in Spain is thoroughly developed, in Ukraine it is at an early stage. Spain's constitutional rules for public administration are logically specific and perfect, but humanistic in Ukraine, but not specific and different. The structure of the Spanish public administration and its legal regulation is perfect, and in Ukraine there is a need to develop an Administrative Procedure Code.

Key words: Administrative activity, Administrative Law, Comparative characteristic, legal nature, Public administration, Spain, Structure of public Administration, Ukraine. 